\title{
The food environment and adult obesity in US metropolitan areas
}

\author{
Akihiko Michimi, Michael C. Wimberly \\ Geospatial Sciences Center of Excellence, South Dakota State University, Brookings, SD, USA
}

\begin{abstract}
This research examines the larger-scale associations between obesity and food environments in metropolitan areas in the United States (US). The US Census County Business Patterns dataset for 2011 was used to construct various indices of food environments for selected metropolitan areas. The numbers of employees engaged in supermarkets, convenience stores, full service restaurants, fast food restaurants, and snack/coffee shops were standardised using the location quotients, and factor analysis was used to produce two uncorrelated factors measuring food environments. Data on obesity were obtained from the 2011 Behavioral Risk Factor Surveillance System. Individual level obesity measures were linked to the metropolitan area level food environment factors. Models were fitted using generalised estimating equations to control for metropolitan area level intra-correlation and individual level sociodemographic characteristics. It was found that adults residing in cities with a large share of supermarket and full-service restaurant workers were less likely to be obese, while adults residing in cities with a large share of convenience store and fast food restaurant workers were more likely to be obese. Supermarkets and full-service restaurant workers are concentrated in the Northeast and West of the US, where obesity prevalence is relatively lower, while convenience stores and fast-food restaurant workers are concentrated in the South and Midwest, where obesity prevalence is relatively higher. The food environment landscapes measured at the metropolitan area
\end{abstract}

Correspondence: Akihiko Michimi, Geospatial Sciences Center of Excellence, South Dakota State University, 1021 Medary Ave, Wecota Hall 115, 506B Brookings, SD, USA.

Tel: +1.605.691.2624.

E-mail: akihiko.michimi@gmail.com

Key words: Food environments; Obesity; Urban; USA.

Acknowledgments: Most of this research was done while the author was a faculty member in the Department of Public Health at Western Kentucky University, Bowling Green, KY, USA.

Received for publication: 7 April 2015.

Revision received: 15 June 2015.

Accepted for publication: 30 June 2015.

(C) Copyright A. Michimi and M.C. Wimberly, 2015

Licensee PAGEPress, Italy

Geospatial Health 2015; 10:368

doi:10.4081/gh.2015.368

This article is distributed under the terms of the Creative Commons Attribution Noncommercial License (by-nc 3.0) which permits any noncommercial use, distribution, and reproduction in any medium, provided the original author(s) and source are credited. level explain the continental-scale patterns of obesity prevalence. The types of food that are readily available and widely served may translate into obesity disparities across metropolitan areas.

\section{Introduction}

Obesity has become a major public health problem with adult obesity prevalence exceeding $30 \%$ globally (Ng et al., 2014). In the United States (US), the age-adjusted adult obesity prevalence was $34.9 \%$ during 2011-2012 and has not changed since 2003-2004 (Ogden et al., 2014). The direct medical cost of overweight and obesity combined is estimated to be about 5 to 10\% of US health care spending (Tsai et al., 2011). Direct associations between obesity and obesity-related diseases such as diabetes, hypertension and heart disease are well known (Malnick and Knobler, 2006), and obese individuals with or without chronic disease conditions may lead to a significantly poorer quality of life than non-obese individuals (Jia and Lubetkin, 2005).

Research shows that disparities in obesity exist by age groups, race/ethnicity and socioeconomic status (McLaren, 2007; Ogden et al., 2010, 2013), but these associations are driven by a more complex set of underlying social and behavioural factors (Wang and Beydoun, 2007). In a low-income community of Baltimore, MD, for example, no racial disparities in obesity have been reported among white and black women sharing similar socioeconomic status (Bleich and Thorpe, 2010). This finding points to a notion that social-environmental factors rather than individual characteristics such as race should be given greater priority in the study of obesity, and that large-scale societal aspects of the environment may influence obesity outcomes (Zhang and Wang, 2012). At the same time, the development of socially and culturally relevant interventions is being encouraged to reduce obesity by promoting healthy lifestyle behaviours (Hill et al., 2014; Sobal, 2001). The food environment has been widely examined in obesity research. Consumption of refined grains, added sugars and added fats are linked to high rates of obesity among lower-income groups (Drewnowski and Darmon, 2005). Fast food restaurants and convenience stores typically stock these energy-dense foods and the availability of these food outlets is greater in low-income than high-income neighbourhoods (Block et al., 2004; Powell et al., 2007b). Fast-food consumption and neighbourhood fast food exposure have been associated with poor diet (Moore et al., 2009). In contrast, supermarkets and grocery stores typically provide people with a large assortment of fresh produce at a relatively low cost, and areas with high densities of supermarkets and grocery stores that are easily accessible are thus assumed to be healthy-food environments that may reduce the risk of obesity for both adults and children (Larsen et al., 2015; Rundle et al., 2009; Morland et al., 2006; Morland and Evenson, 2009). One important implication of the relationship between obesity and the food environment is the cost of diet. Energy-dense foods are more affordable than healthier foods such as fruit and vegetables, and the inability to pay for healthy foods may be responsible for obesity among the poor (Drewnowski, 2004).

Individuals make decisions about their food purchase and consumption within a complex set of social and physical environments. Thus, the spatial 
scale of analysis, from neighbourhood to nation, is an important issue in assessing obesity (Cummins and MacIntyre, 2006). A considerable amount of research has focused on the neighbourhood level analysis of food access (Zenk et al., 2009; Larson et al., 2009), but some suggest that individuals may shop for food outside their residential neighbourhood (Chaix et al., 2012). As a result, associations between food outlets and obesity may also exist for areas that are larger than what typically is considered a neighbourhood (Hattori et al., 2013). This is because travel behaviours for food shopping often encompass multiple neighbourhoods, especially with access to private automobiles and other transportation means. An examination of driving distances found an inverse association between proximity to fastfood restaurants and body mass index (BMI) among the Framingham Heart Study offspring cohort (Block et al., 2011). In addition, low-income adults in California who drive longer time and greater distances to grocery stores are more likely to eat fruits and vegetables (Gase et al., 2014). Therefore, the underlying neighbourhood-level relationships between obesity and food environments may also exist in areas larger than a residential neighbourhood (Hattori et al., 2013).

Using metropolitan areas as a geographic unit is one approach to capturing patterns of access to food that span across multiple neighbourhoods. Each metropolitan area has at least one urban core as well as any adjacent counties that have a high degree of social and economic integration as measured by commuting ties to work with the urban core $(\mathrm{OMB}, 2013)$. It is conceivable that individuals residing in a metropolitan area typically travel in the course of their daily activities and thus have opportunities to shop or dine in areas outside their home neighbourhoods. Exposure to take-away food outlets such as burgers and pizza has been shown to be positively associated with consumption of take-away food, particularly in work rather than home environments (Burgoine et al., 2014). In addition, adults who drive to supermarkets in multiple neighbourhoods embody the idea that people do not necessarily shop at the nearest grocery stores (Drewnowski et al., 2012). Therefore, food environment landscapes measured at the metropolitan area level can provide a novel perspective on food accessibility and its influences on obesity at regional to national levels.

A previous study found that there is variability in the availability of healthy snacks and healthy staple foods among some metropolitan areas (Laska et al., 2010). However, more research is needed to understand how differences in healthy or unhealthy food availability may influence obesity in urban areas across the US. This research adds the new idea that neighbourhood-level associations between obesity and food environments may scale up to the metropolitan area level. These broader-scale relationships may help us understand the determinants of the continental-scale spatial patterns of obesity. The objective of this research is to test the hypothesis that the greater availability of healthy or unhealthy food retailers is associated with obesity prevalence in urban settings. The focus is on 186 selected metropolitan areas across the US.

\section{Materials and Methods}

\section{Datasets used}

Data on obesity by metropolitan area were obtained from the 2011 Behavioral Risk Factor Surveillance System (BRFSS) overseen by the Centers for Disease Control and Prevention (CDC). The BRFSS is an annual cross-sectional telephone survey that collects data from adults (aged over 18 years) living in households by random digit dialling. We used BRFSS Selected Metropolitan/Micropolitan Area Risk Trends (SMART) data, which are a subset of the BRFSS providing some local area estimates measured by metropolitan/micropolitan statistical area (MMSA) and metropolitan divisions as defined by the Office of Management and Budget (OMB). This research used publicly available data from the SMART BRFSS.

The SMART BRFSS included three MMSA area types: i) the metropolitan statistical area; ii) the micropolitan statistical area; and iii) the metropolitan division. A metropolitan statistical area is based on urbanised areas with 50,000 or more population within a county or a group of counties, while a micropolitan statistical area is based on urban clusters of at least 10,000 but less than 50,000 population. In addition, a metropolitan division is a county or a smaller grouping of counties subdivided from a very large metropolitan statistical area. A metropolitan division has a single urbanised area within a metropoli$\tan$ area that has a population of at least 2.5 million (OMB, 2010). For example, the Dallas-Fort Worth-Arlington TX metropolitan area consists of two metropolitan divisions: Dallas-Plano-Irving and Fort WorthArlington. This finer geographic resolution of metropolitan divisions was used to capture the difference in obesity within large metropolitan areas. BRFSS respondents were assigned to one of the MMSA codes based on their county of residence and no individuals were assigned to multiple MMSAs.

There are 198 MMSAs available in 2011 BRFSS SMART data with at least 500 respondents in each MMSA. In order for data to be representative of the population for each local area, the raking methodology (iterative proportional fitting) was utilised to adjust for demographics, social factors (education, marital status, and renter/owner status), and telephone source (CDC, 2014b). Raking is a weighting scheme that allows BRFSS data to incorporate information from land line and cell phone users and, thus, it generates more accurate estimates of the population. The MMSA level weight was generated by raking with additional county-level demographic information (CDC 2014a). This research used the MMSA level weights to provide estimates that were representative of the selected metropolitan areas. Because some MMSAs did not meet the inclusion criteria that were needed for weighting, some states may have fewer numbers of MMSAs compared to other states regardless of states' population sizes.

\section{Employment data}

Data on the number of workers engaged in various food service and retail establishments were obtained from the 2011 U.S. Census County Business Patterns (CBP). The CBP is an annual series that provides employment data classified by the North American Industry Classification System (NAICS), which is useful for studying the economic activity of small areas (US Census Bureau, 2011, 2015). The number of paid employees was used for the analysis to measure relative concentration of food service and retail workers for selected MMSAs. Data for the metropolitan divisions were disaggregated from the larger metropolitan area to include their corresponding county component(s) only.

The types of food service and retail establishments used in this study are summarised in Table 1 . Because of the similarity in the industry definitions, convenience stores (NAICS 445120) and gasoline stations with convenience stores (NAICS 447110) were combined to make a single category entitled convenience store. In addition, limited service restaurants (NAICS 722211) and cafeterias, grill buffets and buffets (NAICS 722212) were also combined to make the single category of fast food restaurant because when the two sectors were combined, the percent of employees was overwhelmingly represented by the former sector (96.4\%) vs the latter (3.6\%). With these adjustments, there were five broad categories of food service and retail establishments that characterised various food environments. These types of food outlets 
are readily accessible to the majority of the population residing in metropolitan communities. Some MMSAs, however, did not report the number of paid employees in some food service and retail categories to ensure disclosure protection. There were 50 MMSAs in NAICS 722212 (cafeterias), 44 MMSAs in NAICS 445120 (convenience stores), 8 MMSAs in NAICS 445110 (supermarkets), 3 MMSAs in NAICS 447110 (gas stations with convenience stores), and 2 MMSAs in NAICS 722213 (snacks and non-alcoholic beverage bars) that did not report employee counts for 2011. Missing values were replaced with imputed data from the previous or subsequent years. Some MMSAs $(n=12)$ were excluded because imputation was not possible. This adjustment resulted in a total of 186 MMSAs included in this study.

\section{Analysis}

The total number of respondents residing in the 186 MMSAs was 300,933 adults registered in BRFSS SMART data. The breakdown of 186 MMSAs was 138 metropolitan areas, 28 micropolitan areas, and 20 metropolitan divisions. This sample represented about 157 million adults living in these selected MMSAs after applying sample weights. Descriptive statistics were calculated for the sample regarding their age, sex, race/ethnicity, educational level, household income, metropol- itan residential status, Census regions and obesity status. Obesity was assessed by respondents' BMI, which was calculated as weight in kilograms divided by height in meters squared $\left(\mathrm{kg} / \mathrm{m}^{2}\right)$. Respondents whose BMI was over $30 \mathrm{~kg} / \mathrm{m}^{2}$ were considered obese. The SAS SURVEYFREQ procedure (SAS, 2015) was used to compute variance estimate based on the sample design. Raking as the source of data weighting incorporated both landline and cell phone interviews along with county demographics in order to make more accurate estimates than the previous methods (CDC, 2014a, 2014b). Ninety five percent confidence intervals (CI) were reported along with weighted proportions to assess sampling variability. The number of paid employees in each MMSA was standardised using location quotient (LQ), which represented the share of local food service and retail industries relative to the national average. $L Q$ was calculated by the percent of employees in a certain industry for a MMSA in the numerator against the percent of the corresponding industry for all US MMSAs in the denominator. If a MMSA has a LQ value greater than 1.0 for a certain industry, that MMSA has a greater share of that industry relative to the national average. $\mathrm{LQ}$ less than 1.0 indicates less share of a certain industry relative to the national average. LQs for the 186 MMSAs were mapped for five categories of food service and retail establishments to visually assess

Table 1. Food service and retail establishments classified by the North American Industry Classification System.

\begin{tabular}{|c|c|c|c|}
\hline Code & Description & Industry definition & Category \\
\hline 445110 & $\begin{array}{l}\text { Supermarkets and other grocery } \\
\text { (except convenience) stores }\end{array}$ & $\begin{array}{l}\text { Retailing a general line of food, such as canned and frozen foods, } \\
\text { fresh fruit and vegetables, fresh and prepared meats, fish and poultry. } \\
\text { Delicatessen-type establishments are included }\end{array}$ & Supermarket \\
\hline 445120 & Convenience stores & $\begin{array}{l}\text { Retailing a limited line of convenience items that generally include } \\
\text { bread, soft drinks, snacks, tobacco products, newspapers, household } \\
\text { paper and cleaning products, canned goods and alcohol beverages }\end{array}$ & $\begin{array}{l}\text { Convenience } \\
\text { store }\end{array}$ \\
\hline 447110 & $\begin{array}{l}\text { Gasoline stations with } \\
\text { convenience store }\end{array}$ & $\begin{array}{l}\text { Retailing automotive fuels combined with the retail sale of a limited } \\
\text { line of merchandise, such as milk, bread, soft drinks, and snacks in a } \\
\text { convenience store setting }\end{array}$ & $\begin{array}{l}\text { Convenience } \\
\text { store }\end{array}$ \\
\hline 722110 & Full-service restaurants & $\begin{array}{l}\text { Providing food services to patrons who order and are served while } \\
\text { seated and pay after eating }\end{array}$ & $\begin{array}{l}\text { Full service } \\
\text { restaurant }\end{array}$ \\
\hline 722211 & Limited service restaurants & $\begin{array}{l}\text { Providing food services where patrons generally order } \\
\text { or select items and pay before eating. } \\
\text { Food may be consumed on premises, taken out, } \\
\text { or delivered to the customers' location }\end{array}$ & $\begin{array}{l}\text { Fast food } \\
\text { restaurant }\end{array}$ \\
\hline 722212 & Cafeterias, grill buffets, and buffets & $\begin{array}{l}\text { Preparing and serving meals for immediate consumption using cafeteria } \\
\text { style or buffet serving equipment, as well as self-service non-alcoholic } \\
\text { beverage dispensing equipment }\end{array}$ & $\begin{array}{l}\text { Fast food } \\
\text { restaurant }\end{array}$ \\
\hline 722213 & $\begin{array}{l}\text { Snacks and non-alcoholic beverage } \\
\text { bars }\end{array}$ & $\begin{array}{l}\text { Preparing and/or serving specialty snacks, such as ice cream, frozen } \\
\text { yogurt, cookies, coffee, juices, or sodas for consumption on or near the } \\
\text { premises as well as selling related products (e.g. coffee beans, mugs) }\end{array}$ & $\begin{array}{l}\text { Snack/coffee } \\
\text { shop }\end{array}$ \\
\hline
\end{tabular}

Table 2. Food service establishment components by rotated factor patterns with factor loadings greater than 0.5.

\begin{tabular}{|c|c|c|c|}
\hline Factor & FL & NAICS Code - sector description & Factor summary \\
\hline 1 & $\begin{array}{l}0.818 \\
0.777 \\
0.698\end{array}$ & $\begin{array}{c}445110 \text { - Supermarkets and other grocery (except convenience) stores } \\
722213 \text { - Snacks and non-alcoholic beverage bars } \\
722110 \text { - Full-service restaurants }\end{array}$ & More quality/healthy options with supermarket dominance \\
\hline 2 & $\begin{array}{l}0.793 \\
0.745\end{array}$ & $\begin{array}{c}\text { 722211/722212 - Limited service restaurants; } \\
\text { cafeterias, grill buffets, and buffets } \\
\text { 445120/447110 - Convenience stores; } \\
\text { gasoline stations with convenience stores }\end{array}$ & Less quality/healthy options with fast food dominance \\
\hline
\end{tabular}

FL, factor loading. 
spatial variability (Figure 1). LQs for these five categories were examined as a MMSA level metric of variability in food service and retail industries to explain the likelihood of obesity at the individual level.

Because some food service and retail industries may be correlated with respect to food provision and quality, an additional analysis was undertaken to see if findings were sensitive to the specific method of quantifying food environments. Factor analysis identified the underlying food environment structure and shared variance among the five food service and retail categories. An orthogonal rotation was used to produce uncorrelated factors. Thus, each factor represented unique information about the food service and retail environments. Two fac- tors were extracted by the following criteria: eigenvalue greater than one; Varimax rotation with Kaiser Normalization; and rotation conversion within three iterations (Table 2).

All significant factor loadings were positive $(\geq 0.5)$ making the interpretation of MMSA level factor scores straightforward. Factor 1 was correlated with supermarkets, snack/coffee shops, and full service restaurants, while factor 2 was correlated with fast food and convenience stores. Factor scores from these two factors were obtained by regression, which produced standardised metrics similar to $\mathrm{z}$ scores, (DiStefano et al., 2009) and they were mapped for each MMSA (Figure 2). These two maps, consolidated from five LQ maps, summarised a

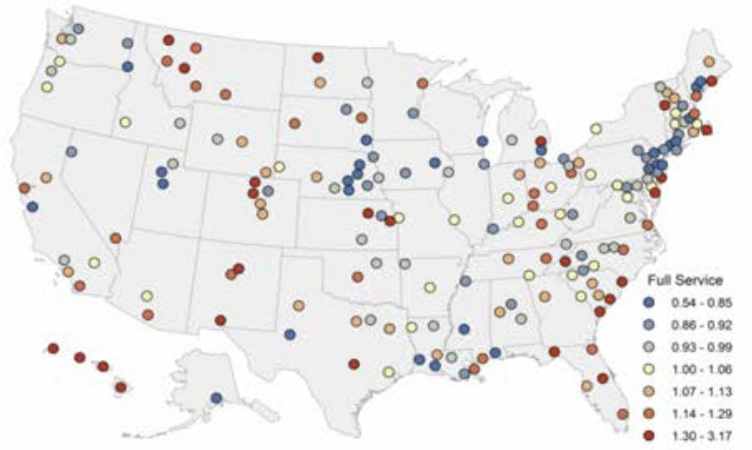

C

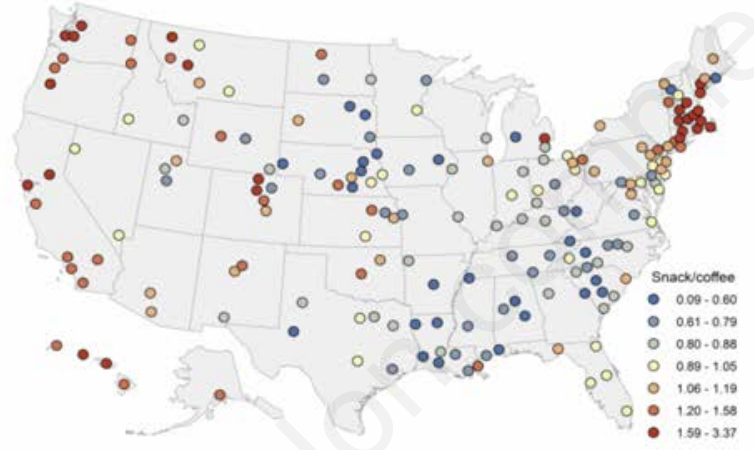

e

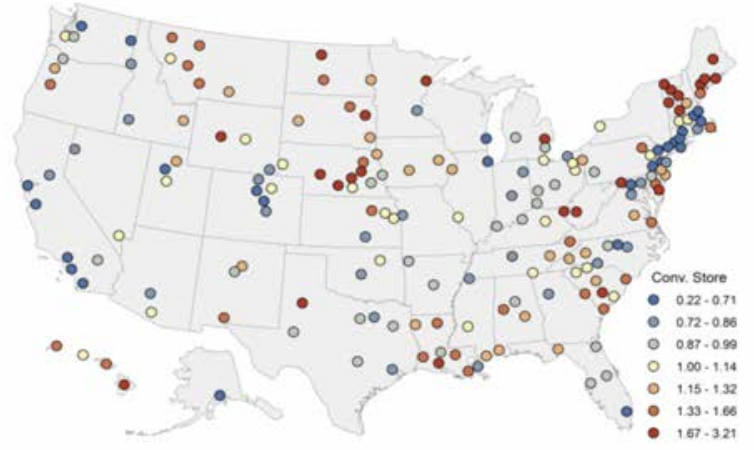

b

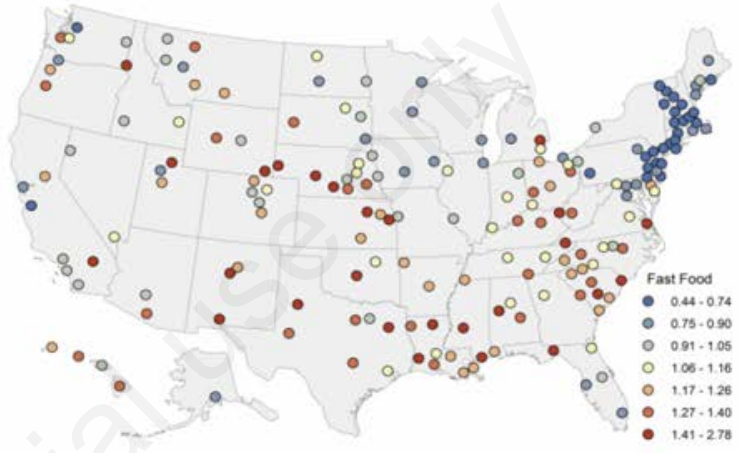

d

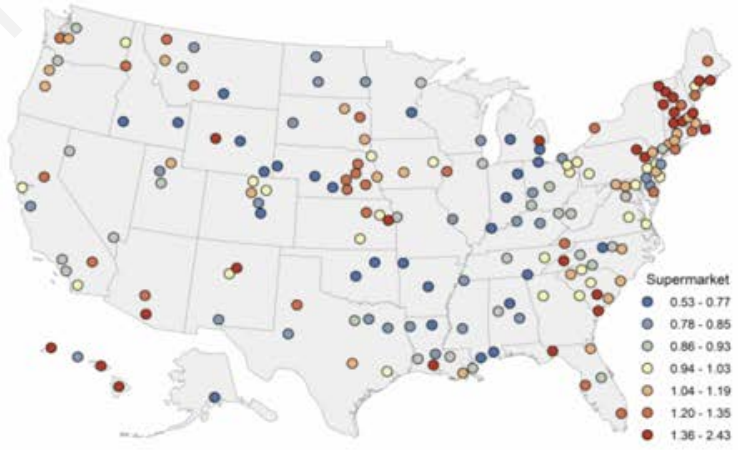

f

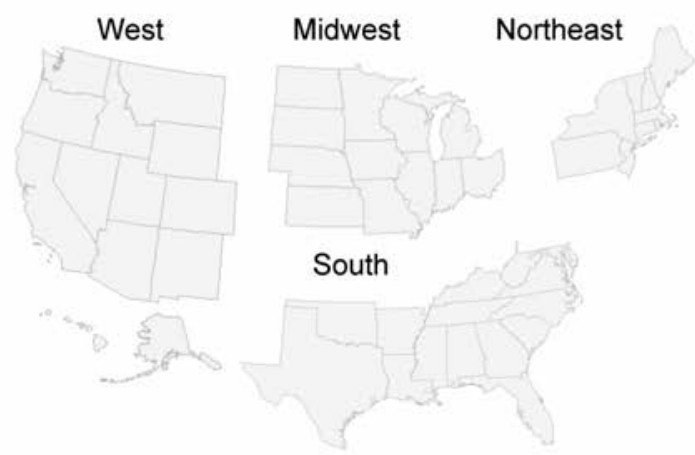

Figure 1. Location quotients for 186 metropolitan/micropolitan statistical areas: a) full-service restaurant workers; b) fast-food restaurant workers; c) snack/coffee shop workers; d) supermarket workers; e) convenience store workers; f) census regions. Quantile method is used for class intervals for all maps. 
broadly-defined food service and retail landscapes that each shared similar characteristics. These two factors were assessed separately from the LQs.

Multilevel logistic regression models were developed for obesity drawn from BRFSS data. Respondents were classified into obese and non-obese groups using BMI $30 \mathrm{~kg} / \mathrm{m}^{2}$ as the cut-off point. Covariates included age, sex, race/ethnicity, education, and income to control for individual-level characteristics. MMSA residential status was included to control for city size, and Census regions were included to control for spatial clusters of obesity prevalence as reported previously (Michimi et al., 2010b). LQs and factor scores for each MMSA were linked with BRFSS data. At the MMSA-level, LQs from the five food service and retail industries and two factors were modelled separately. Models were fitted using the SAS GENMOD procedure, which uses generalised estimating equations to account for MMSA-level intra-correlation and nested structure of individuals within metropolitan areas. Odds ratios (OR) estimates and 95\% CI for the individual- and MMSA-level variables were reported. All analyses were performed using SAS version 9.3 and MMSA-level weights were used to generate representative population estimates from selected MMSAs.

\section{Results}

The sample characteristics are summarised in Table 3 . Age was relatively evenly distributed across the six age groups. There were slightly more females (51.4\%) than males in this sample. About $62.3 \%$ were non-Hispanic white, while $37.5 \%$ were non-Hispanic black, Hispanic or other groups representing some racial/ethnic diversity of metropolitan populations. Large proportions of the sample had some college education (29.9\%) or were college graduates (29.4\%). About $31.6 \%$ of the sample had annual household income of greater than $\$ 75,000$, while $12.3 \%$ had less than $\$ 15,000$. For MMSA status, about $68.7 \%$ resided in metropolitan areas or mid-sized cities, while $30.0 \%$ resided in metropolitan divisions or very large cities. Respondents living in the South were represented the most in the sample (34.0\%). According to the BMI, $26.0 \%$ of the respondents were obese.

ORs from the two models are summarised in Table 4. For the model including LQs, obesity prevalence increased with age especially for the middle-aged groups, compared to the youngest group (18 to 24 years old). Males were more likely to be obese, compared to females. Blacks and Hispanics were more likely to be obese, while the Other group was less likely to be obese, compared to white. Higher education and income generally reduced the risk for obesity. There was no difference in obesity prevalence with respect to the MMSA status. Adults living in the Midwest and South were more likely to be obese, compared to those living in the West. For food establishment LQs, adults living in MMSAs with a large share of full service restaurants and supermarkets were less likely to be obese, while those living in MMSAs with a large share of fast-food restaurants, convenience stores and snack/coffee shops were more likely to be obese. Notably, supermarket workers were more concentrated in the Northeast than in other regions (Figure 1d). Fastfood workers, on the contrary, were more concentrated in the southern MMSAs than the northeastern MMSAs (Figure 1b).

For the model including the two factors, ORs for covariates remained similar to the model including LQs. Factor 1 consisting of supermarkets, snack/coffee shops and full-service restaurants was significant. Adults living in MMSAs with a greater share in these food service and retail industries were less likely to be obese. Factor 2, consisting of convenience stores and fast food restaurants, was also significant. In contrast to Factor 1, adults living in MMSAs with a greater share in these food service and retail industries were more likely to be obese.

\section{Discussion}

This research shows that the relative concentration of various food service and retail workers plays an important role in explaining the obesity prevalence among adults living in US metropolitan areas. In urban settings, populations served by more full-service restaurant and a

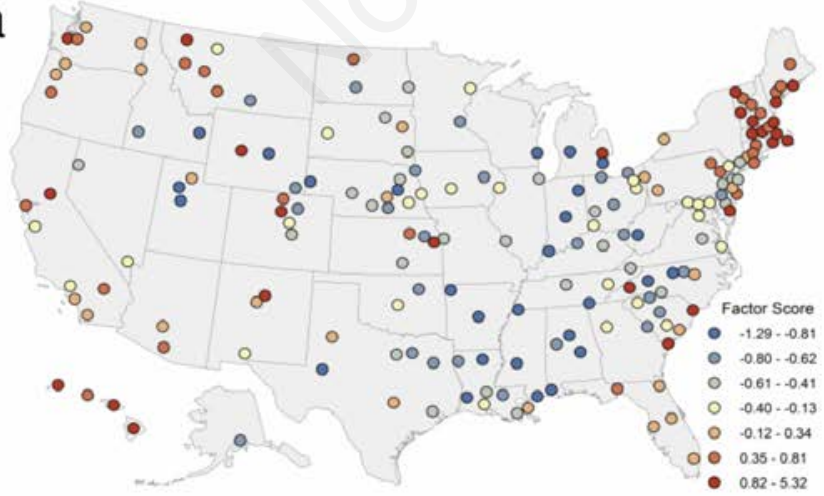

b

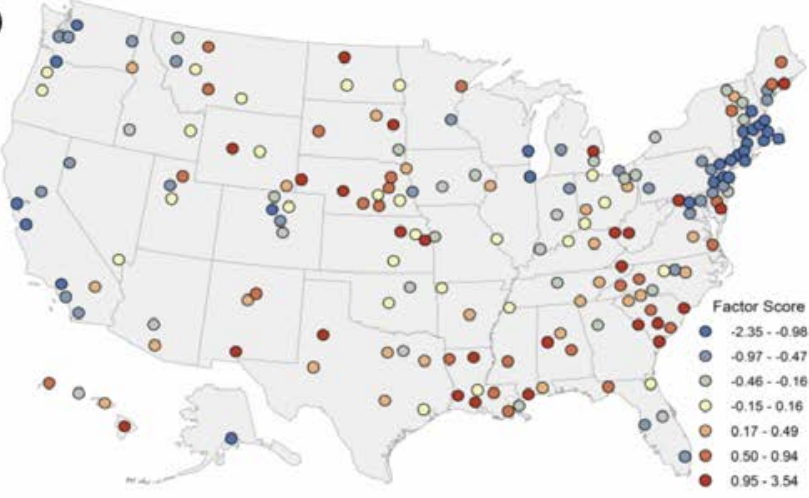

Figure 2. Factor scores for 186 metropolitan/micropolitan statistical areas: a) factor 1 composed of supermarkets, snack/coffee, and fullservice restaurants; b) factor 2 composed of convenience stores and fast food restaurants. Quantile method is used for class intervals for all maps. 
supermarket workers are less likely to be obese, while populations served by more fast-food restaurant and convenience store workers are more likely to obese. These findings support the idea that the abundance of food outlets that generally provide healthy or unhealthy diet can influence obesity at the scale of broad urban areas. This relationship is perhaps due to greater provision and availability of food with varying nutritional quality that people are exposed on a regular basis (Swinburn et al., 2004). Results may also be related (in part) to varying demand for types of food among adults living in different places (Pitts et al., 2013).

The demand for food-away-from-home has important implications for people's diet and health. A previous study estimated that the per capita spending on both full-service and fast food restaurants may rise between 2000 and 2020 assuming modest growth in household income (Stewart et al., 2004). Greater availability and demand for fast food has led to increased fast food consumption, (Jekanowski et al., 2001) and the link between energy-dense fast-food intake and the epidemic of obesity has been widely reported (Prentice and Jebb, 2003; Garcia et $a l ., 2012)$. In addition, fast food restaurants are more available in lower to middle income and predominantly black communities, compared to high income and white communities in urban areas (Powell et al., 2007a). Our research supports the general consensus on the association between fast food availability and higher obesity prevalence and emphasises that such relationships also exist at the metropolitan area level.

The quality of food served in fast-food $v$ f full-service restaurants differs, which may impact obesity outcomes. Full-service restaurants often provide a variety of healthier food options to respond to the needs of health-conscious patrons, and profit margins are the main reason why restaurants do or do not offer healthy food options (Glanz et al., 2007). Young adults who use full-service restaurants frequently are more likely to eat healthy foods, and their dietary intake patterns are not related to weight status (Larson et al., 2011; Duffey et al., 2007). Counties with a higher density of full service restaurants are associated with lower weight status suggesting a more healthful eating environment, (Mehta and Chang, 2008) and proximity to restaurants providing fast food, but not full service, are correlated with weight gain (Currie et al., 2010). Our research suggests that the obesity prevalence may mirror the food environment where fast food or full service restaurant industries dominate the metropolitan food landscape.

Food prepared at home has another important dimension in the relationship between food consumption and health. In 2007-08, foods from the home supply accounted for 65 to $72 \%$ of total daily energy intake among adults in the U.S (Smith et al., 2013). Adults are more likely to eat healthy foods if they have more time to spend on food preparation at home, while working adults who spend less time on cooking place a high priority on convenience, which leads to more frequent use of fast food (Monsivais et al., 2014). If supermarkets provide a large assortment of fresh produce at a relatively lower cost than convenience stores (Broda et al., 2009), it is conceivable that populations in areas with more supermarkets would have lower obesity prevalence, while populations in areas with more convenience stores would have higher obesity prevalence (Morland et al., 2006). In addition, people living in metropolitan counties with higher supermarket accessibility are more likely to eat fruits and vegetables and less likely to be obese (Michimi et al., 2010a). Thus, food availability and accessibility may explain how people prepare and consume food, and such social and cultural practices related to diet may influence obesity outcomes.

Large concentrations of workers in supermarkets, snack/coffee shops, and full-service restaurants shown in Figure $2 \mathrm{a}$ are mostly found in the northeastern cities and parts of the West where obesity prevalence is relatively lower. The food outlet landscape represented in Figure $2 b$, on the contrary, shows a reverse pattern of Figure $2 a$ in many paired cities. Convenience store and fast-food restaurant workers are more concentrated in parts of the southern and midwestern cities where obesity prevalence is relatively higher. These regional clusters of food outlets that offer generally healthier, or unhealthier food options coincide with county-based estimates of lower and higher obesity prevalence in the continental US (Michimi et al., 2010b). We propose that the relationship between food environments and obesity is, in part, driven by broader regional patterns of food availability represented by metropolitan-area-level food environments. Food consumption, for example, is largely cultural and food preference is recognised in different regions of the US (Shortridge, 2003). Regional food environment landscapes are often ignored in neighbourhood scale analysis, thus findings in our research are particularly useful in regional planning that aims to reduce obesity by improving healthy food provision.

Several limitations should be noted. First, local neighbourhood effects that may exist within a large city were not assessed because data finer than the metropolitan area level were not available and because this research was focused on differences between various US

Table 3. Descriptive statistics of the sample population with $\mathbf{9 5 \%}$ confidence intervals.

\begin{tabular}{|c|c|}
\hline & $\%(95 \%$ CI $)$ \\
\hline $\begin{array}{l}\text { Age (years) } \\
\quad 18-24 \\
25-34 \\
35-44 \\
45-54 \\
55-64 \\
\geq 65\end{array}$ & $\begin{array}{l}12.4(12.1,12.8) \\
18.6(18.3,18.9) \\
18.3(18.0,18.6) \\
19.1(18.8,19.4) \\
14.8(14.5,16.0) \\
16.5(16.3,16.7)\end{array}$ \\
\hline $\begin{array}{l}\text { Sex } \\
\quad \text { Male } \\
\quad \text { Female }\end{array}$ & $\begin{array}{l}48.5(48.2,48.9) \\
51.4(51.0,51.7)\end{array}$ \\
\hline $\begin{array}{l}\text { Race/ethnicity } \\
\text { Non-hispanic white } \\
\text { Non-hispanic black } \\
\text { Hispanic } \\
\text { Other }\end{array}$ & $\begin{array}{c}62.3(61.9,62.7) \\
12.9(12.6,13.2) \\
16.0(15.7,16.4) \\
8.6(8.3,8.8)\end{array}$ \\
\hline $\begin{array}{l}\text { Educational level } \\
<\text { High school } \\
\text { High school } \\
\text { Some college } \\
\text { College graduate }\end{array}$ & $\begin{array}{l}13.9(13.5,14.2) \\
26.6(26.3,27.0) \\
29.9(29.6,30.2) \\
29.4(29.1,29.7)\end{array}$ \\
\hline $\begin{array}{l}\text { Household income (\$) } \\
\quad<15,000 \\
15,000-24,999 \\
25,000-49,999 \\
50,000-74,999 \\
\geq 75,000\end{array}$ & $\begin{array}{l}12.3(12.0,12.6) \\
17.0(16.7,17.3) \\
23.8(23.5,24.1) \\
15.0(14.7,15.3) \\
31.6(31.3,32.0)\end{array}$ \\
\hline $\begin{array}{l}\text { MMSA status } \\
\text { Metropolitan division } \\
\text { Metropolitan area } \\
\text { Micropolitan area }\end{array}$ & $\begin{array}{c}30.0(29.6,30.4) \\
68.7(68.4,69.1) \\
1.2(1.1,1.2)\end{array}$ \\
\hline $\begin{array}{l}\text { Census region } \\
\text { Northeast } \\
\text { Midwest } \\
\text { South } \\
\text { West }\end{array}$ & $\begin{array}{l}20.7(20.4,21.0) \\
19.5(19.2,19.8) \\
34.0(33.6,34.4) \\
25.5(25.2,25.9)\end{array}$ \\
\hline $\begin{array}{l}\text { Obesity } \\
\text { BMI } 30 \mathrm{~kg} / \mathrm{m}^{2}\end{array}$ & $26.0(25.7,26.3)$ \\
\hline
\end{tabular}

BMI, body mass index. Missing data were excluded. Values in brackets represent $95 \%$ confidence interval. 
metropolitan areas. Metropolitan area boundaries delineated by predetermined administrative unit measures can result in spatial misclassification by incorrectly characterising a neighbourhood-level exposure (Duncan et al., 2014) and possibly result in the modifiable areal unit problems (MAUP) (Wong, 2004). Second, obesity data generated from self-reported weight and height are known to be underestimated compared to measured data (Yun et al., 2006), so findings may be subject to recall bias. Third, food environments are becoming increasingly diverse as some fast-food chain restaurants may offer healthy meal options and convenience stores may carry healthy snacks. Therefore, more precise classification of food retail activities should be part of the future research agenda. Fourth, although supermarkets often provide affordable healthy foods, cost of similar food items may differ by residential areas. In such cases, food prices along with food availability may play an interacting role in obesity outcomes (Drewnowski et al., 2012). In addition, obesity and food environments may be influenced by more complex social networking with respect to how people obtain food from various sources other than food retailers (Christakis and Fowler,
2007). Finally, cross-sectional data used in this research only allowed a correlational framework, and no causal inferences between obesity and risk exposures were assessed. Also, the odds ratios reported in our study may overestimate the effect because the obesity outcome was relatively high, thus estimates may not precisely measure the risk ratios in this study (Cummings, 2009).

\section{Conclusions}

Adults living in cities with a large share of supermarket and full-service restaurant workers are less likely to be obese, while those living in cities with a large share of convenience store and fast-food restaurant workers are more likely to be obese. These metropolitan food environment landscapes are likely shaped by increased availability of and demand for different types of food that people regularly seek or prefer, and the obesity prevalence may be responding to these food environ-

Table 4. Odds ratios for obesity with $95 \%$ confidence intervals.

\begin{tabular}{|c|c|c|}
\hline & OR ( $95 \%$ CI) & OR ( $95 \%$ CI) \\
\hline $\begin{array}{l}\text { Age (years) (ref. 18-24) } \\
\quad 25-34 \\
\quad 35-44 \\
45-54 \\
\quad 55-64 \\
\quad \geq 65\end{array}$ & $\begin{array}{l}2.02(1.81,2.25)^{* *} \\
2.67(2.44,2.93)^{* *} \\
3.09(2.75,3.47)^{* *} \\
3.10(2.86,3.37)^{* *} \\
2.12(1.89,2.39)^{* *}\end{array}$ & $\begin{array}{l}2.01(1.81,2.24)^{* *} \\
2.66(2.43,2.92)^{* *} \\
3.07(2.74,3.44)^{* *} \\
3.09(2.84,3.35)^{* *} \\
2.10(1.88,2.36)^{* *}\end{array}$ \\
\hline $\begin{array}{l}\text { Sex (ref. female) } \\
\text { Male }\end{array}$ & $1.06(1.01,1.12)^{*}$ & $1.06(1.01,1.12)^{*}$ \\
\hline $\begin{array}{l}\text { Race/ethnicity (ref. white) } \\
\text { Black } \\
\text { Hispanic } \\
\text { Other }\end{array}$ & $\begin{array}{l}1.64(1.55,1.73)^{* *} \\
1.23(1.15,1.32)^{* *} \\
0.61(0.54,0.69)^{* *}\end{array}$ & $\begin{array}{l}1.62(1.53,1.71)^{* *} \\
1.19(1.11,1.29)^{* *} \\
0.60(0.53,0.68)^{* *}\end{array}$ \\
\hline $\begin{array}{l}\text { Education (ref. <high school) } \\
\text { High school } \\
\text { Some college } \\
\text { College graduate } \\
\end{array}$ & $\begin{array}{c}0.97(0.91,1.03) \\
0.98(0.91,1.05) \\
0.64(0.60,0.69)^{* *} \\
\end{array}$ & $\begin{array}{c}0.97(0.91,1.03) \\
0.98(0.91,1.05) \\
0.64(0.60,0.68)^{* *} \\
\end{array}$ \\
\hline $\begin{array}{l}\text { Income }(\$)(\text { ref. }<15,000) \\
15,000-24,999 \\
25,000-49,999 \\
50,000-74,999 \\
\geq 75,000\end{array}$ & $\begin{array}{c}0.96(0.89,1.03) \\
0.89(0.83,0.95)^{* *} \\
0.91(0.85,0.98)^{*} \\
0.72(0.67,0.77)^{* *}\end{array}$ & $\begin{array}{c}0.96(0.89,1.03) \\
0.89(0.84,0.95)^{* *} \\
0.91(0.85,0.98)^{*} \\
0.72(0.68,0.77)^{* *}\end{array}$ \\
\hline $\begin{array}{l}\text { MMSA status (ref. micro) } \\
\text { Metropolitan division } \\
\text { Metropolitan area } \\
\end{array}$ & $\begin{array}{l}1.00(0.84,1.18) \\
1.01(0.86,1.18)\end{array}$ & $\begin{array}{l}0.98(0.85,1.07) \\
0.98(0.89,1.08)\end{array}$ \\
\hline $\begin{array}{l}\text { Census region (ref. West) } \\
\text { Northeast } \\
\text { Midwest } \\
\text { South }\end{array}$ & $\begin{array}{c}1.07(0.97,1.18) \\
1.15(1.08,1.23)^{* *} \\
1.15(1.08,1.24)^{* *}\end{array}$ & $\begin{array}{c}1.08(0.97,1.21) \\
1.12(1.05,1.19)^{* *} \\
1.07(0.98,1.17)\end{array}$ \\
\hline $\begin{array}{l}\text { Food establishment LQ } \\
\text { Full service restaurant } \\
\text { Fast food restaurant } \\
\text { Snack/coffee } \\
\text { Supermarket } \\
\text { Convenience store }\end{array}$ & $\begin{array}{l}0.73(0.64,0.83)^{* *} \\
1.24(1.11,1.39)^{* *} \\
1.09(1.01,1.19)^{*} \\
0.83(0.73,0.95)^{* *} \\
1.27(1.15,1.45)^{* *}\end{array}$ & \\
\hline $\begin{array}{l}\text { Food establishment factor }^{\circ} \\
\text { Factor } 1 \text { (more healthy options) } \\
\text { Factor } 2 \text { (less healthy options) }\end{array}$ & & $\begin{array}{l}0.94(0.90,0.98)^{* *} \\
1.09(1.05,1.13)^{* *}\end{array}$ \\
\hline
\end{tabular}

$\mathrm{CI}$, confidence interval; LQ, location quotient. Five establishment location quotient measures (middle column) and 2 factors of food environments (right column) were modelled separately. Missing data were excluded. Values in brackets represent $95 \%$ confidence interval. ${ }^{\circ}$ See Table 2 for the description of Factors 1 and $2 .{ }^{*} \mathrm{P}<0.05 ;{ }^{* *} \mathrm{P}<0.01$. 
ments across the US metropolitan areas. Findings from this research can be useful for developing and targeting public health interventions that aim to reduce obesity by promoting healthy diet in urban settings.

\section{References}

Bleich SN, Thorpe Jr RJ, 2010. Social context explains race disparities in obesity among women. J Epidemiol Commun $\mathrm{H}$ 64:465-9.

Block JP, Christakis NA, O'Malley J, Subramanian SV, 2011. Proximity to food establishments and body mass index in the Framingham Heart Study offspring cohort over 30 years. Am J Epidemiol 174:1108-14.

Block JP, Scribner RA, DeSalvo KB, 2004. Fast food, race/ethnicity, and income: a geographic analysis. Am J Prev Med 27:211-7.

Broda C, Leibtag E, Weinstein DE, 2009. The role of prices in measuring the poor's living standards. J Econ Perspect 23:77-97.

Burgoine T, Forouhi NG, Griffin SJ, Wareham NJ, Monsivais P, 2014. Associations between exposure to takeaway food outlets, takeaway food consumption, and body weight in Cambridgeshire, UK: population based, cross sectional study. Brit Med J 348:1464.

CDC 2014a. 2011 SMART BRFSS MMSA methodology. CDC, Atlanta, GA, USA.

CDC 2014b. Behavioral Risk Factor Surveillance System (BRFSS) fact sheet: raking. CDC, Atlanta, GA, USA.

Chaix B, Bean K, Daniel M, Zenk SN, Kestens Y, Charreire H, Leal C, Thomas F, Karusisi N, Weber C, Opert J-M, Simon C, Merio J, Pannier B, 2012. Associations of supermarket characteristics with weight status and body fat: a multilevel analysis of individuals within supermarkets (RECORD Study). PLoS One 7:332908.

Christakis NA, Fowler JH, 2007. The spread of obesity in a large social network over 32 years. New Engl J Med 357:370-9.

Cummings $P, 2009$. The relative merits of risk ratios and odds ratios. Arch Pediatr Adolesc Med 163:438-45.

Cummins S, MacIntyre S, 2006. Food environments and obesity - neighbourhood or nation? Int J Epidemiol 35:100-4.

Currie J, Della Vigna S, Morett, E, Pathania V, 2010. The effect of fast food restaurants on obesity and weight gain. Available from: www.nber.org/papers/w14721.pdf

DiStefano C, Zhu M, Mindrila D, 2009. Understanding and using factor scores: considerations for the applied researcher. Practical Assessment, Research \& Evaluation 14:1-11.

Drewnowski A, 2004. Obesity and the food environment: dietary energy density and diet costs. Am J Prev Med 27:154-62.

Drewnowski A, Aggarwal A, Hurvitz PM, Monsivais P, Moudon AV, 2012. Obesity and supermarket access: proximity or price? Am J Public Health 102:74-80.

Drewnowski A, Darmon N, 2005. The economics of obesity: dietary anergy density and energy cost. Am J Clin Nutr 82(1 Suppl):265S$73 \mathrm{~S}$.

Duffey KJ, Gordon-Larsen P, Jacobs Jr DR, Williams OD, Popkin BM, 2007. Differential associations of fast food and restaurant food consumption with 3-y change in body mass index: the coronary artery risk development in young adults study. Am J Clin Nutr 85:201-8.

Duncan DT, Kawachi I, Subramanian SV, Aldstadt J, Melly SJ, 2014. Examination of how neighborhood definition influences measurements of youths' access to tobacco retailers: a methodological note on spatial misclassification. Am J Epidemiol 179:373-81.

Garcia G, Sunil TS, Hinojosa P, 2012. The fast food and obesity link: consumption patterns and severity of obesity. Obes Surg 22:810-8.
Gase LN, DeFosset AR, Smith LV, Kuo T, 2014. The association between self-reported grocery store access, fruit and vegetable intake, sugar-sweetened beverage consumption, and obesity in a racially diverse, low-income population. Front Public Health 2:229.

Glanz K, Resnicow K, Seymour J, Hoy K, Stewart H, Lyons M, Goldberg J, 2007. How major restaurant chains plan their menue: the role of profit, demand, and health. Am J Prev Med 32:383-8.

Hattori A, An R, Sturm R, 2013. Neighborhood food outlets, diet, and obesity among California adults, 2007 and 2009. Prev Chronic Dis 10:E35.

Hill JL, You W, Zoellner JM, 2014. Disparities in obesity among rural and urban residents in a health disparate region. BMC Public Health 14:1051.

Jekanowski MD, Binkley JK, Eales J, 2001. Convenience, accessibility, and the demand for fast food. J Agr Resour Econ 26:58-74.

Jia H, Lubetkin EI, 2005. The impact of obesity on health-related quality-of-life in the general adult US population. J Public Health 27:156-64.

Larsen K, Cook B, Stone MR, Faulkner GE, 2015. Food access and children's BMI in Toronto, Ontario: assessing how the food environment relates to overweight and obesity. Int J Public Health 60:6977.

Larson N, Neumark-Sztainer D, Laska MN, Story M, 2011. Young adults and eating away from home: associations with dietary intake patterns and weight status differ by choice of restaurant. J Am Diet Assoc 111:1696-703.

Larson NI, Story MT, Nelson MC, 2009. Neighborhood environments: disparities in access to healthy foods in the U.S. Am J Prev Med $36: 74-81$.

Laska MN, Borradaile KE, Tester J, Foster GD, Gittelsohn J, 2010. Healthy food availability in small urban food stores: a comparison of four US cities. Public Health Nutr 13:1031-5.

Malnick SDH, Knobler H, 2006. The medical complications of obesity. QJM-Int J Med 99:565-79.

McLaren L, 2007. Socioeconomic status and obesity. Epidemiol Rev 29:29-48.

Mehta NK, Chang VW, 2008. Weight status and restaurant availability a multilevel analysis. Am J Prev Med 34:127-33.

Michimi A, Wimberly MC, 2010a. Associations of supermarket accessibility with obesity and fruit and vegetable consumption in the conterminous United States. Int J Health Geogr 9:49.

Michimi A, Wimberly MC, 2010b. Spatial patterns of obesity and associated risk factors in the conterminous U.S. Am J Prev Med 39:e1-e12.

Monsivais P, Aggarwal A, Drewnowski A, 2014. Time spent on home food preparation and indicators of healthy eating. Am J Prev Med 47:796-802.

Moore LV, Diez Roux AV, Nettleton JA, Jacobs DR, Franco M, 2009. Fastfood consumption, diet quality, and neighborhood exposure to fast foode: the multi-ethnic study of atherosclerosis. Am J Epidemiol 170:29-36.

Morland K, Diez Roux AV, Wing S, 2006. Supermarkets, other food stores, and obesity: the atherosclerosis risk in communities study. Am J Prev Med 30:333-9.

Morland K, Evenson K, 2009. Obesity prevalence and the local food environment. Health Place 15:491-5.

Ng M, Fleming T, Robinson M, Thomson B, Graetz N, Margono C, Mullany EC, Biryukov S, Abbafati C, Abera SF, Abraham JP, AbuRmeileh NM, Achoki T, AlBuhairan FS, Alemu ZA, Alfonso R, Ali MK, Ali R, Guzman NA, Ammar W, Anwari P, Banerjee A, Barquera S, Basu S, Bennett DA, Bhutta Z, Blore J, Cabral N, Nonato IC, Chang JC, Chowdhury R, Courville KJ, Criqui MH, Cundiff DK, 
Dabhadkar KC, Dandona L, Davis A, Dayama A, Dharmaratne SD, Ding EL, Durrani AM, Esteghamati A, Farzadfar F, Fay DF, Feigin VL, Flaxman A, Forouzanfar MH, Goto A, Green MA, Gupta R, Hafezi-Nejad N, Hankey GJ, Harewood HC, Havmoeller R, Hay S, Hernandez L, Husseini A, Idrisov BT, Ikeda N, Islami F, Jahangir E, Jassal SK, Jee SH, Jeffreys M, Jonas JB, Kabagambe EK, Khalifa SE, Kengne AP, Khader YS, Khang YH, Kim D, Kimokoti RW, Kinge JM, Kokubo Y, Kosen S, Kwan G, Lai T, Leinsalu M, Li Y, Liang X, Liu S, Logroscino G, Lotufo PA, Lu Y, Ma J, Mainoo NK, Mensah GA, Merriman TR, Mokdad AH, Moschandreas J, Naghavi M, Naheed A, Nand D, Narayan KM, Nelson EL, Neuhouser ML, Nisar MI, Ohkubo T, Oti S0, Pedroza A, Prabhakaran D, Roy N, Sampson U, Seo H, Sepanlou SG, Shibuya K, Shiri R, Shiue I, Singh GM, Singh JA, Skirbekk V, Stapelberg NJ, Sturua L, Sykes BL, Tobias M, Tran BX, Trasande L, Toyoshima H, van de Vijver S, Vasankari TJ, Veerman JL, Velasquez-Melendez G, Vlassov VV, Vollset SE, Vos T, Wang C, Wang X, Weiderpass E, Werdecker A, Wright JL, Yang YC, Yatsuya H, Yoon J, Yoon SJ, Zhao Y, Zhou M, Zhu S, Lopez AD, Murray CJ, Gakidou E, 2014. Global, regional, and national prevalence of overweight and obesity in children and adults during 1980-2013: a systematic analysis for the Global Burden of Disease Study 2013. Lancet 384:766-81.

Ogden CL, Carroll MD, Kit BK, Flegal KM, 2013. Prevalence of obesity among adults: United States, 2011-2012. NCHS Data Brief 2013:18.

Ogden CL, Carroll MD, Kit BK, Flegal KM, 2014. Prevalence of childhood and adult obesity in the United States, 2011-2012. J Am Med Assoc 311:806-14.

Ogden CL, Lamb MM, Carroll MD, Flegal KM, 2010. Obesity and socioeconomic status in adults: United States, 2005-2008. NCHS Data Brief Dec 2010:1-8.

OMB 2010. 2010 Standards for delineating metropolitan and mecropolitan statistical areas; notice. Office of Management and Budget, Federal Register, Washington, DC, USA.

OMB 2013. Revised delineations of metropolitan statistical areas, micropolitan statistical areas, and combined statistical areas, and guidance on uses of the delineations of the these areas. Office of Management and Budget, Federal Register, Washington, DC, USA.

Pitts SB, Bringolf KR, Lloyd CL, McGuirt JT, Lawton KK, Morgan J, 2013. Formative evaluation for a healthy corner store initiative in Pitt County, North Carolina: engaging stakeholders for a healthy corner store initiative, part 2. Prev Chronic Dis 18:E120.

Powell LM, Chaloupka FJ, Bao Y, 2007a. The availability of fast-food and full-service restaurants in the United States: associations with neighborhood characteristics. Am J Prev Med 33:240-5.

Powell LM, Slater S, Mirtcheva D, Bao Y, Chaloupka FJ, 2007b. Food store availability and neighborhood characteristics in the United
States. Prev Med 44:189-95.

Prentice AM, Jebb SA, 2003. Fast foods, energy density and obesity: a possible mechanistic link. Obes Rev 4:187-94.

Rundle A, Neckerman KM, Freeman L, Lovasi GS, Purciel M, Quinn J, Richards C, Sircar N, Weiss C, 2009. Neighborhood food environment and walkability predict obesity in New York City. Environ Health Persp 117:442-7.

SAS, 2015. SAS/STAT 9.3 User's Guide. SAS Institute Inc., Cary, NC, USA.

Shortridge BG, 2003. A food geography of the Great Plains. Geogr Rev 93:507-29.

Smith LP, Ng SW, Popkin BM, 2013. Trends in US home food preparation and consumption: analysis of national nutrition surveys and time use studies from 1965-1968 to 2007-2008. Nutr J 12:45.

Sobal J, 2001. Social and cultural influences on obesity: international textbook of obesity. John Wiley \& Sons Ltd, New York, NY, USA.

Stewart H, Blisard N, Bhuyan S, Nayga Jr RM, 2004. The demand for food away from home: full service or fast food? USDA Department of Agriculture, Washington, DC, USA.

Swinburn BA, Caterson I, Seidell JC, James WPT, 2004. Diet, nutrition and the prevention of excess weight gain and obesity. Public Health Nutr 7:123-46.

Tsai AG, Williamson DF, Glick HA, 2011. Direct medical cost of overweight and obesity in the United States: a quantitative systematic review. Obes Rev 12:50-61.

US Census Bureau, 2011. County business patterns. Available from: http://www.census.gov/econ/cbp/

US Census Bureau, 2015. North American Industry Classification System. Available from: http:/www.census.gov/eos/www/naics/

Wang Y, Beydoun MA, 2007. The obesity epidemic in the United States. Gender, age, socioeconomic, racial/ethnic, and geographic characteristics: a systematic review and meta-regression analysis. Epidemiol Rev 29:6-28.

Wong DWS, 2004. The modifiable areal unit problem (MAUP). In: Janelle DG, Warf B, Hansen K, eds. WorldMinds: geographical perspectives on 100 problems. Springer, Berlin, Germany, pp 571-575.

Yun S, Zhu B-P, Black W, Brownson RC, 2006. A comparison of national estimates of obesity prevalence from the behavioral risk factor surveillance system and the national health and nutrition examination survey. Int J Obesity 30:164-70.

Zenk SN, Schulz AJ, Odoms-Young A, 2009. How neighborhood environments contribute to obesity. Am J Nurs 109:61-4.

Zhang Q, Wang Y, 2012. Trends in the association between obesity and socioeconomic status in U.S. adults: 1971-2000. Obesity 12:162232 . 